Revista do CESP, Belo Horizonte, v.36, n.56, p. 95-97, 2016

\title{
COELHO, Alexandra Lucas. Deus-dará. Lisboa: Tinta-da-China, 2016. 568 p.
}

Bruno Mazzolini de Barros

Pontifícia Universidade Católica do Rio Grande do Sul - PUCRS brunomazolini@gmail.com

Deus-dará, o último romance da portuguesa Alexandra Lucas Coelho, não é a sua primeira incursão textual no além-mar: o Brasil já aprece, por exemplo, na coletânea de crônicas recolhidas em Vai, Brasil (Tinta da China, 2013) e em seu romance anterior, Meu amante de domingo (Tinta da China, 2014). A autora, jornalista que já esteve radicada em Jerusalém e no Rio de Janeiro, apresenta em Deus-dará uma topografia antropológica e histórica da segunda capital do Brasil.

Já em uma espécie de subtítulo, na folha de rosto, o tempo, o espaço e as personagens da narrativa são apresentados: "Sete dias na vida de São Sebastião do Rio de janeiro, ou o apocalipse segundo Lucas, Judite, Zaca, Tristão, Inês, Gabriel \& Noé". A estrutura da oração já sublinha o protagonismo da capital, afinal são sete dias, primeiramente, da vida da cidade. As referências bíblicas também já estão anunciadas aí, nos sete dias de criação ou nos nomes próprios, apesar de o apocalipse do romance ser o maia, até então anunciado para 2012, e de o texto ser tomado por diversas referências culturais além das cristãs.

Desde o início do romance, seja por meio de epígrafes, referências históricas e a própria vida das personagens, há uma constante intersecção entre o contemporâneo, o histórico e o mítico, sejam de origem indígena, africana, árabe ou europeia. O texto está estruturado em sete dias, distribuídos entre os anos de 2012, 2013 e 2014, e consegue delinear um olhar crítico tanto para Portugal quanto para o Brasil. A ênfase, no entanto, é neste último, levantando problemas histórico-socias que têm origens no processo colonizador, na ascensão e conflitos de classes, nas 
políticas sociais (sejam as aplicadas ou as desprezadas) e na latente e onipresente questão racial do país.

Tudo isso aparece entrecruzado à vida de Lucas, mestiço de negro, de índio e de branco, ascensorista e estudante universitário; Judite, advogada de um escritório de luxo, descendente de sírios; Zaca, irmão de Judite, escritor com romance em processo de pesquisa e composição; Tristão, português antropólogo que fotografa favelas; Inês, doutoranda portuguesa que desembarca no Rio vinda de Lisboa depois de uma temporada em Beirute; Gabriel, sociólogo, professor, negro de origem humilde; e Noé, mulata bolsista de ciências políticas na PUC, babá nas horas vagas.

A visão aguçada do narrador em relação ao Brasil e o contorno que ele faz da vida das personagens dá, na verdade, um protagonismo maior à cidade: é um romance-inventário do Rio de Janeiro, cujo o epicentro é o Cosme Velho de Machado de Assis. É Cosme Velho de favelas, mas também o Cosme Velho de mansões como a da famosa família Marinho: toda a contradição que é o Rio de Janeiro e, de certa forma, mesmo o Brasil, sintetizado em um bairro e nas vidas que circulam por ali.

No entanto, a partir dessa região da cidade, as personagens e narrador navegam também por outras áreas: Barra da Tijuca, Cidade de Deus, Lapa, Copacabana, Ipanema, Complexo do Alemão, Saara e até a serra fluminense. Nessas incursões, tem-se acesso a uma cidade onde observa-se, por exemplo, a onipresença de $O$ Globo na vida da classe média carioca e de diferentes formas de violência que parecem conduzir a vida na periferia.

O romance está permeado por cartas, mapas, música popular, livros, pichação, poesia, cartões postais, fotografias, diários: tudo usado como suporte na figuração de um Rio de Janeiro como selva-cidade ou cidade-selva, entre morro e mar, entre mata e concreto, entre bairro nobre e periferia, entre os que fazem faxina e os que fazem análise, entre os que andam de ônibus e os que andam de helicóptero, como observa-se na própria narrativa. Em meio a isso tem-se o Cosme Velho, uma "selva com favela" (p. 357), assim como o é a própria cidade de São Sebastião do Rio de Janeiro ou, curiosamente, o Brasil na visão estereotipada de alguns estrangeiros.

É importante destacar o narrador na tecitura de Deus-dará, que às vezes apresenta alguns registros de "carioquês", apesar de não abandonar a dicção portuguesa totalmente. Além disso, ele deixa claro 
seu status de narrador ficcional onisciente, e até onipotente, quando exume-se, ironicamente, da culpa da morte de uma das personagens periféricas do romance. Sua ironia e sagacidade, assim com alguns narradores machadianos, descreve bem a sociedade carioca com termos como "casa grande ecofriendly" (p. 56). Na última parte do romance, ele performatiza-se cada vez mais, onde abundam expressões como "então o narrador acha" (p. 448), "o narrador decide como quer" (p. 451) ou "Você, que me seguiu até aqui, sabe que gosto de gigantes vermelhas" (p. 542), chegando a assumir a primeira pessoa no discurso narrativo.

Outro destaque no romance é a presença das relações promíscuas entre a iniciativa privada e o estado fluminense nos anos pré-olímpicos. Dentre elas, figuram inclusive as entre o empresário Eike Batista e o exgovernador Sérgio Cabral, atualmente presos. O narrador até engana-se no que diz respeito ao futuro de uma das personagens, Tomás Cavendish: "o narrador desconfia que ele nunca pisará uma daquelas prisões brasileiras" (p. 388). Essa personagem divide não só o sobrenome, mas também parte da biografia, com o empresário e engenheiro Fernando Cavendish, que, fora do romance, está encarcerado por envolvimento em corrupção.

O texto, tomado de problematizações acerca de questões relacionadas à história, à antropologia, à política e à economia, é um romance mais sobre o Rio de Janeiro do que sobre o Brasil. Tomar a cidade como representante do todo seria incorrer na estereotipização de um país grande e complexo, apesar de este dividir com a cidade muitos de seus problemas e belezas, como explicita bem Deus-dará. 